CORRECTION

\title{
Correction to: Diversity and evolution of surface polysaccharide synthesis loci in Enterobacteriales
}

Kathryn E. Holt (D), Florent Lassalle (D), Kelly L. Wyres, Ryan Wick (D) and Rafał J. Mostowy

(C) The Author(s) 2022

The ISME Journal (2022) 16:1478; https://doi.org/10.1038/s41396-021-01181-9

Correction to: The ISME Journal 14:1713-1730 https://doi.org/ 10.1038/s41396-020-0628-0, published online 6 April 2020

In this article was given Cronobacter sakazakii incorrectly as Citrobacter sakazakii.

The original article has been corrected.

\begin{abstract}
(c) (i)
Open Access This article is licensed under a Creative Commons distribution and reproduction in any medium or format, as long as you give appropriate credit to the original author(s) and the source, provide a link to the Creative Commons license, and indicate if changes were made. The images or other third party material in this article are included in the article's Creative Commons license, unless indicated otherwise in a credit line to the material. If material is not included in the article's Creative Commons license and your intended use is not permitted by statutory regulation or exceeds the permitted use, you will need to obtain permission directly from the copyright holder. To view a copy of this license, visit http://creativecommons. org/licenses/by/4.0/.
\end{abstract}

(c) The Author(s) 2022 